\section{The role of beluntas (pluchea indica less.) leaf extract in preventing the occurrence of fibroblasts hyperproliferation: An in vitro preliminary study}

\author{
Sakti Charlia Maharani, Indah Julianto, \\ Suci Widhiati \\ Dermato-venereology Department, \\ Medical Faculty of Sebelas Maret \\ University, Dr. Moewardi General \\ Hospital, Surakarta, Indonesia
}

\begin{abstract}
Beluntas (Pluchea indica Less.) is a herbal plant which contains variety of benefits. Quercetin, one of flavonoid, is the most bioactive agent in beluntas leaf. Collagen inhibition by quercetin may modulate extracellular matrix deposition and inhibit the formation of hypertrophic scar. This was an in vitro study with senescent fibroblasts to determine the role of beluntas leaf extract in preventing the occurence of fibroblasts hyperproliferations. There were 4 groups were stained by anti-collagen I antibodies and secondary antibody. Flowcytometry analysis was done to measure the fibroblasts density. Anova test was performed with a value of $p=0.000(p<0.05)$. A post hoc analysis showed significant differences in the average decrease of fibroblasts that absorbs staining anti-collagen I antibody treatment group compared with the control group. There were significant effects of beluntas leaf extract in preventing the occurrence of fibroblasts hyperproliferations. Beluntas leaf extract with a concentration of $80 \mathrm{~mol} / \mathrm{L}$ had the most significant effect on the fibroblasts density. Thus beluntas leaf extract has the ability in preventing the occurrence of fibroblasts hyperproliferation.
\end{abstract}

\section{Introduction}

In the last few decades, various scientific studies involving herbal medicinal plants has evolved. Plants remain as important source of new drugs. Plants have been utilized as medicine for thousands of years. In search for better treatment option, many patients have turn to alternative medicine in the hopes of identifying more natural substances with less toxicity but equal efficacy. The World Health Organization (WHO) study reported that the use of herbal medicinal plants has low side effects, cheaper, and easily obtainable. ${ }^{1,2}$ Beluntas (Pluchea indica Less.) has the bioactive content as phytochemicals mainly flavonoids, triterpenoids, phenols, sterols, glycosides and essential oils. ${ }^{3}$ Flavonoids are divided into several classes one of which is flavonols containing quercetin, the most compound in beluntas. ${ }^{4}$ Quercetin was previously reported has antioxidant and antifibrotic activity. ${ }^{2}$

Normal fibroblasts work to regulate synthesis collagen in the dermis. ${ }^{5}$ Dermis composed connective tissue contains fibroblasts and collagen. The role of fibroblasts in producing extracellular matrix (ECM)-forming agents is crucial not only as the development and maintenance of normal tissue structures, but also improvements and reshuffle in the wound healing process. ${ }^{6}$ Fibroblast fibers are used in vitro studies as a model because fibroblasts are the primary producer of collagen in the dermis layer, especially type I collagen, to study wound healing and scar. Collagen inhibition by quercetin may modulate extracellular matrix deposition and inhibit the formation of hypertrophic scar. ${ }^{7,8}$ Since there has never been reported before, the authors hypotezised that there are role in beluntas leaf extract for preventing the occurence of fibroblasts hyperproliferation.

\section{Materials and Methods}

Invitro study was conducted from September 2016 to February 2017 in Dr. Moewardi General Hospital, Dermama Biotechnology Laboratory Surakarta and the Agricultural and Development Research Institute of Spices and Medicines Ministry of Agriculture (BALLITRO) Bogor. Beluntas leaf extract was taken from Pawana kepurun Indonesia company in Yogyakarta. The antibodies anti-collagen I was purchased from cambridge, United Kingdom. The sample study used fibroblast cultures obtained from human placenta. The inclusion criteria was placenta obtained from woman who gave birth to a healthy baby, HBsAg negative examination, nonreactive anti HIV test, and was willing to sign informed consent while the exclusion criteria was a woman with a genetic disease associated with collagen abnormalities and unwilling to participate in the study. Beluntas leaf extract is an extract obtained from beluntas plant which is divided into 3 concentrations, $20 \mu \mathrm{mol} / \mathrm{L}, 40 \mu \mathrm{mol} / \mathrm{L}$, and $80 \mu \mathrm{mol} / \mathrm{L}$. Type I collagen deposition was calculated using flowcytometer over cultured fibroblasts with starvation of $1 \%$ fetal bovine serum (FBS) and treated with 3 concentration of beluntas leaf extract. The
Correspondence: Sakti Charlia Maharani, Dermato-venereology Department, Medical Faculty of Sebelas Maret University, Dr. Moewardi General Hospital, Kolonel Sutarto street no. 132, Surakarta, Central Java, Indonesia.

Phone: 0271-634848

E-mail: sakticmaharani@gmail.com

Key words: Beluntas, fibroblasts, hyperproliferation.

Contributions: The authors contributed equally.

Conflict of interest: The authors declare no potential conflict of interest.

Received for publication: 1 February 2019. Accepted for publication: 7 February 2019.

This work is licensed under a Creative Commons Attribution-NonCommercial 4.0 International License (CC BY-NC 4.0).

(C)Copyright S.C. Maharani et al., 2019 Licensee PAGEPress, Italy

Dermatology Reports 2019; 11(s1):8019 doi:10.4081/dr.2019.8019

measurement result was the percentage of antibodies anticolagen I absorbed by senescence fibroblasts. This study was approved by Dr.Moewardi General Hospital ethical committee.

The difference of type I collagen deposition from the control group and the treatment groups was analyzed by one-way ANOVA and post hoc test. Primary antibodies are used to bind to collagen type I specific collagen I protein antigen. Secondary antibody is intended for immunolabeling. This study used primary antibodies AntiCollagen I antibody [5D8-G9] ab23446 $(A b c a m \AA)$ and secondary antibody Goat Anti-Mouse IgG H \& L (Alexa Fluor ${ }^{\circledR}$ 488) $\left(\right.$ Abcam $\left.{ }^{\circledR}\right)$. Primary Antibodies AntiCollagen I antibody [5D8-G9] ab23446 $\left(\right.$ Abcam $\left.{ }^{\circledR}\right)$ has been used in studies of human type IV collagen, whereas the use of Goat Anti-Mouse IgG H \& L (Alexa Fluor ${ }^{\circledR}$ 488) (Abcam $\left.{ }^{\circledR}\right)$ has also been used as secondary antibodies in the study of tight junctions (TJs) and adherent junctions (AJs) of adenocarcinoma epithelial cells in humans. Although derived from mice, these antibodies have cross-adsorption with IgG and human serum.

\section{Results}

The culture of senescence fibroblasts showed that giving beluntas leaf extract had an effect on decreasing the amount of 
fibroblasts which absorb type I collagen antibody. The higher concentration of beluntas leaf extract given, the less the number of cells that absorbed type I collagen antibody shown by the decreased of fibroblasts density (Figure 1). Flowcytometry analysis showed that the number of detected cells absorbed decreased along with the large amount of beluntas leaf extract given (Figure 2).

The normality test between groups after flowcytometry analysis with Shapiro-Wilk showed $p$ value $>0.05$ in all samples, therefore that the sample in this study is homogeneous. Levene test was done to analyze the variance between groups, and the result was $\mathrm{p}>0.05$ meaning this study had the same variance so that it met the requirement of ANOVA test. The result of ANOVA test on four different treatments showed the value of $p<0.05$. It could be assumed that there was a significant effect on the different concentrations of beluntas extracts to the deposition of senescence fibroblasts (Table 1).

\section{Discussion}

Based on the results of phytochemical tests of the Agricultural Research and Development of Indonesian Spice and Medicinal Plant Research Institute Bogor, leaf extract qualitatively contains flavonoids. In the ANOVA extract test of leaf beluntas with concentration of $20 \mu \mathrm{mol}$ / L, $40 \mu \mathrm{mol} / \mathrm{L}$, and $80 \mu \mathrm{mol} / \mathrm{L}$ was shown to have an effect on inhibiting the fibroblasts density on senescence fibroblast cultures and was statistically significant with $\mathrm{p}=0.000 \quad(\mathrm{p}<0.05)$ so that the research hypothesis is accepted. Among the treatment groups, the concentration of beluntas leaf extract of $80 \mu \mathrm{mol} / \mathrm{L}$ had the greatest inhibitory effects on fibroblasts density. It was concluded that the concentration of beluntas leafs $80 \mu \mathrm{mol} / \mathrm{L}$ was the highest concentration to preventing the fibroblasts hyperproliferations and was statistically significant $p=0.000 \quad(p<0.05)$. This is in

Table 1. The results of ANOVA test measurements of the independent and dependent variables.

\begin{tabular}{lcc} 
Groups & $\begin{array}{c}\text { Fibroblasts } \\
\text { density }\end{array}$ & p \\
Control & $1.5 \%$ & 0.000 \\
Beluntas $20 \mu \mathrm{mol} / \mathrm{L}$ & $1.3 \%$ & 0.000 \\
\hline Beluntas $40 \mu \mathrm{mol} / \mathrm{L}$ & $1.0 \%$ & 0.000 \\
Beluntas $80 \mu \mathrm{mol} / \mathrm{L}$ & $0.7 \%$ & 0.000 \\
\hline
\end{tabular}

accordance with previous research which stated that this inhibitory effect has the maximum effect at $80 \mu \mathrm{mol} / \mathrm{L}$ concentration with lethal dose was achieved at an extract concentration of $100 \mu \mathrm{mol} / \mathrm{L}$. The decrease in fibroblasts hyperproliferations in the administration of beluntas leaf extract is made possible by the content of quercetin as flavonoids in beluntas which gives effect on inhibition of collagen synthesis, by interfering the biosynthesis of collagen precursor molecules known as procollagen. ${ }^{9}$ It has always been very easy to get fibroblasts to multiply in vitro, they are commonly accused of swamping the growth of other kinds of cells in a culture. ${ }^{10}$ Normal fibroblasts work to regulate synthesis and degrade collagen in the dermis. The senescence fibroblasts are fibroblasts that lose their

$A$
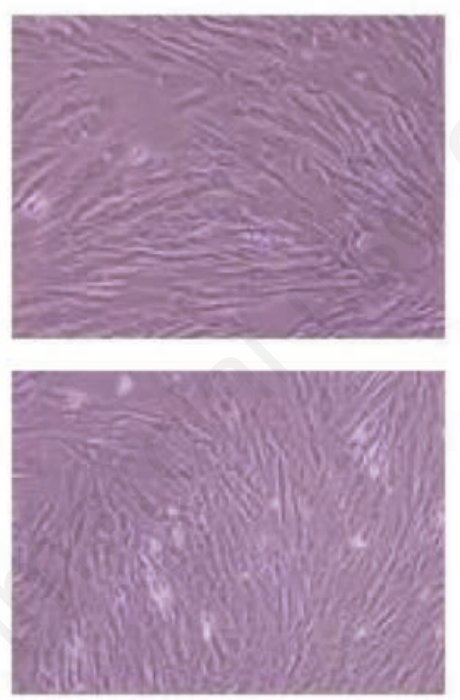

E
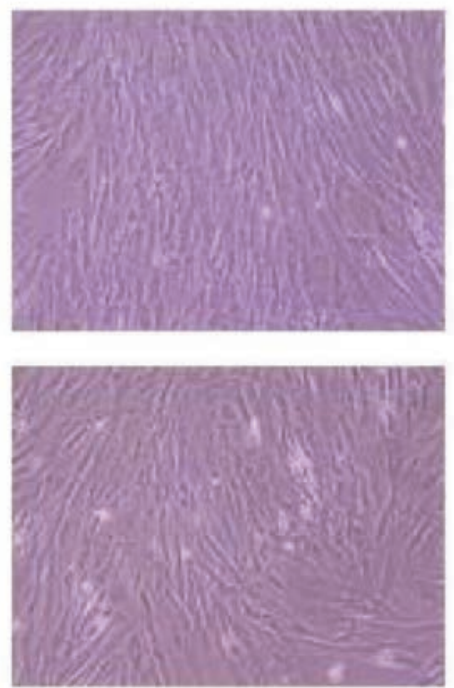

ability to produce collagen, procollagen and Tissue Inhibitors of Matrix Metalloproteinases (TIMP). Hence senescence fibroblasts mimick the patological process of chronic inflammatory response. ${ }^{11}$ The increased presence of type III collagen at the beginning of the tissue repair phase, is physiologically perceived as the onset of miofibroblasts early in the tissue repair phase. However, in the pathological process, there is a significant increase in the number of type III collagen in the whole process, which can result in the formation of scar in the normal dermis. ${ }^{12,13}$ Increased collagen synthesis is a major problem especially in the fibrotic tissue repair response due to cellular damage and / or chronic inflammatory response. In inflammatory lesions, fibrin may serve to induce local

B

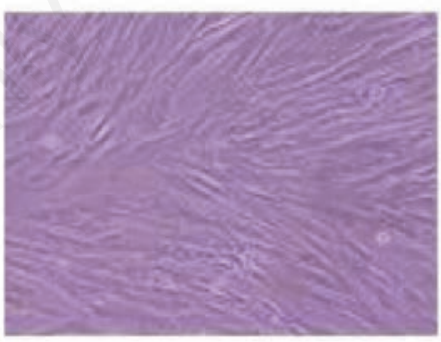

D

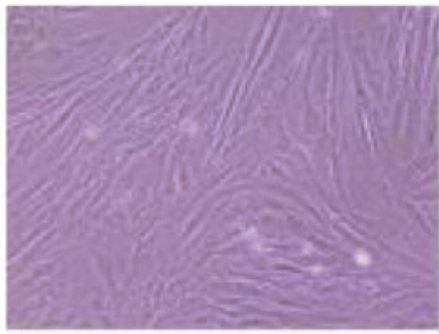

F

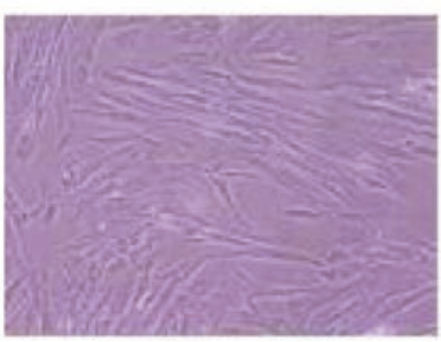

H

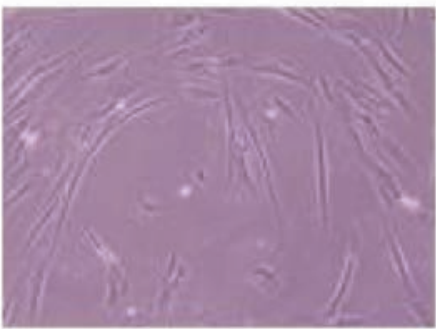

Figure 1. The distribution of fibroblasts in starvation cultures. A-B. Control groups. C. Group 2 before treatment. D. Group 2 after giving beluntas leaf extract at concentration of $20 \mathrm{~mol} / \mathrm{L}$. E. Group 3 before treatment. F. Group 3 after extract of beluntas leaves with concentration of $40 \mathrm{~mol} / \mathrm{L}$. G. Group 4 before treatment. H. Group 4 after giving beluntas leaf extract with concentration of $80 \mathrm{~mol} / \mathrm{L}$. The density of the cell decreases as the concentration of beluntas leaf extract increases 


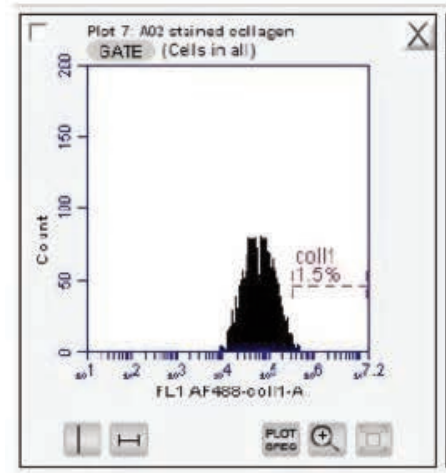

A

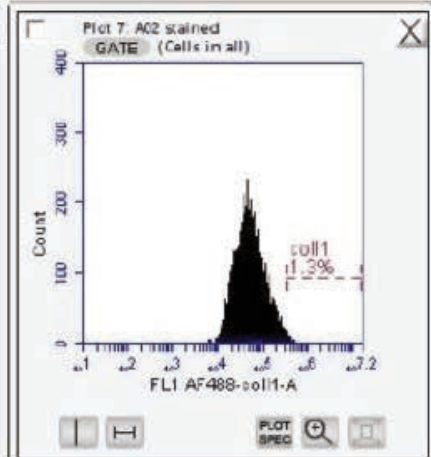

B

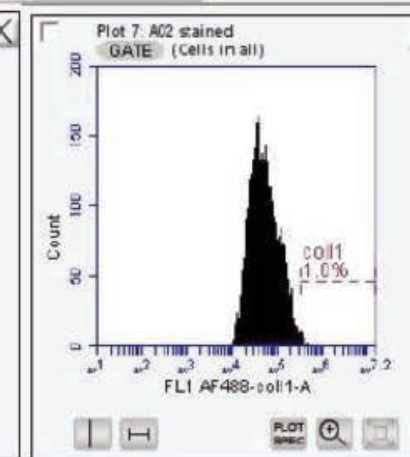

C

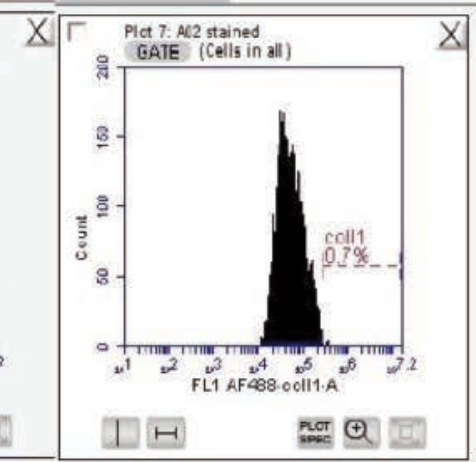

D

Figure 2. A. The results of flowcytometric analysis of group 1 (control), B. group 2 (treatment with beluntas extract with $20 \mu$ mol / L concentration), C. group 3 (treatment with beluntas extract with concentration of $40 \mu \mathrm{mol} / \mathrm{L}$ ), D. group 2 (treatment with extract beluntas with a concentration of $80 \mu \mathrm{mol} / \mathrm{L}$ ).

fibroblast response. This becomes important in the early stages of increased collagen synthesis after tissue inflammation. The amount of fibrin will be determined by the location and nature of the damaged cell, and the fibrin will again stimulate the fibrotic response. Fibroplasia will be reduced by the decrease in fibrin deposition, by increased fibrinolysis, resulting from decreased and stabilized collagen synthesis, or due to increased collagen degradation. ${ }^{12,14,15}$ The limitation of this study is the calculation of beluntas leaf extract concentration was based on relative molecular mass and quercetin content in 100 grams of dried extract of beluntas leaf and not on pure quercetin extract.

\section{Conclusions}

There was significant effect of beluntas leaf extract in preventing the occurrence of fibroblasts hyperproliferations. Beluntas leaf extract with a concentration of $80 \mathrm{~mol} /$ $\mathrm{L}$ had the most significant effect on the fibroblasts density. Our study revealed that beluntas leaf extract has the ability in preventing the occurrence of fibroblasts hyperproliferation. This is an invitro preliminary study, thus further study needs to be performed invivo.

\section{References}

1. Kumar Pal dan Shukla. Herbal medicine: current atatus and the future. Asian Pacific J Canc Prevent 2003;4: 281-8.

2. Ezhilarasan D, Sokal E, Karthikeyan S, Najimi M. Plants derived antioxidant and antifibrotic drugs: past, present and future. J Coas Life Med 2014;2:738-45.

3. Goyal PK, Aggarwal RR. A review on Phytochemical and biological investidation of plant genus pluchea. Indo Am J Pharm Res 2013;3:3373-91.

4. Suriyaphan O. Nutrition, health benefits and application of Pluchea indica (L.) leaves. Mahidol Univ J Pharm Sci 2014;41:1-10.

5. Vandeberg JS, Rudolph R, et al. Fibroblas senescence in preasure ulcers. Wound Rep Reg 1998;6:38-49.

6. Viennet C, Tissot M, Lallam C, Muret P. Identity and phenotype of cultured human gingival and skin fibroblasts. Wound Rep Reg 2015;23:A1-A37.

7. Atiyeh BS, Amm CA, Kusai A, El
Musa. Improved scar quality following primary and secondary healing of cutaneous wounds. Aesth Plast Surg 2003;27:411-7.

8. Rangraj A. Role of collagen in wound management. Wounds Uk 2011;7:5463.

9. Stipcevic T, Piliac J. Effects on different flavonoids on collagen synthesis in human fibroblast. Plant Foods Human Nutr 2006;1-6.

10. Abercrombie M. Fibroblast. J Clin Path 1978;12:1-6.

11. Vandeberg JS, Rudolph R. Fibroblas senescence in preasure ulcers. Wound Rep Reg 1998;6:38-49.

12. Minor RR. Collagen metabolism. Am J Pathol 1980;98:228-67.

13. Sandhu SV, Gupta S, Bansal H, Singla K. Collagen in Health and Disease. J Orofacial Res 2012;2:153-9.

14. McAnulty RJ. Fibroblas and myofibroblas: their source, function and role in disease. Int J Biochem Cell Biol 2006;39:666-71.

15. Cheng W, Yanhua R. The content and ratio of type I and III collagen in skin differ with age and injury. Afric J Biotechnol 1999;10:2524-9. 